\title{
The Influence of Career Management to Perceived Job Performance of Bahrainis in Ebrahim Khalil Kanoo in the Kingdom of Bahrain
}

\author{
Manar Nader Alarrayedh ${ }^{1}$ and Dr. Mark P. Doblas ${ }^{2}$ \\ ${ }^{1}$ MBA Student, College of Financial and Administrative Sciences, AMA International University, KINGDOM OF BAHRAIN \\ ${ }^{2}$ Assistant Professor, College of Financial and Administrative Sciences, AMA International University, KINGDOM OF
}

BAHRAIN

${ }^{1}$ Correspondence Author: mano0or22@live.com

\begin{abstract}
Like most organizations, EKK recognizes that career management is essential in achieving organizational objectives. In fact, it prides itself as one of the country's best in terms of managing employee career growth. As well as it has an existing career management which been established from 1999 till now which is 20 years ago. However, it has been noted that there is yet a formal study conducted in EKK to assess the Influence of Career Management to Job Performance of Bahrainis. Thus, this study aims to assess the influence of Career Management Implementation to Perceived Job Performance of Bahrainis in Ebrahim Khalil Kanoo in the kingdom of Bahrain. The study utilized a descriptive research design involving 162 sampled respondents. The research made use of an adopted questionnaire as data gathering tool. The results of the study showed that over-all implementation of Career Management influences perceived employee performance. In addition, the study also found that among all dimensions of Career Management assessed in the study, Basic, Formal, Active Planning and Active Management Activities significantly influence Perceived Employee Performance. Finally, Multi-Directional Activity does not significantly influence perceived employee performance.
\end{abstract}

Keywords - Active Management, Active Planning, Basic Activity Career Management, formal Activity, Perceived Employee Performance, Multi Directional

\section{INTRODUCTION}

Ebrahim Khalil Kanoo (EKK) served Bahrain for more than fifty years. The company's core business is automotive retail and sales, as well the after sales service activities, for automobile owners' in the Kingdom. The company has more than 2700 employee. It is a well-known international automobile brand provider that agents popular products of Volvo, Isuzu, Subaru, Cherry, Sangung, Lexus, Toyota, Mercantile, Michelin, and McLaren. The company also operates Tyre Plus and Zibart, Kanoo Vehicle Leasing, Kanoo daily rental and Kanoo pre-owner vehicle. As well as it has an existing career management which been established from 1999 till now which is 20 years ago.
Like most organizations, EKK recognizes that career management is essential in achieving organizational objectives. In fact, it prides itself as one of the country's best in terms of managing employee career growth. As Adamson and others (2015) noted, the importance of career management it is not only organizations benefit from an effective career management system, but also the individual employee. They suggest that a career can assist individuals in the way that it offers structure, direction, meaning, and purpose to daily activities.

Having a career can furthermore imply other important consequences such as the financial return after having invested time and labor in the employing organization. A well-functioning career management system will therefore to some extent ensure both an organized working environment as well as the satisfaction of basic economic needs and other higher needs such as for example self-actualization and personal development needs thus helps in the fulfillment of the psychological contract.

A well-working career management framework will thusly to some degree guarantee both a composed workplace just as the fulfillment of fundamental monetary necessities and other higher needs such as self-completion and self-improvement needs causes it to satisfaction of the mental contract. However, it has been noted that there is yet a formal study conducted in EKK to assess the Influence of Career Management to Job Performance of Bahrainis.

Orpen (2014) has studied the relationship between job performance and the management in a variety of organizations both in private and public sectors in UK. He studied career effectiveness in terms of salary growth, promotion received, career performance and career satisfaction. From the factor analysis conducted in his study, he identified three components of organizational career management, which includes career information, career management policies and career development. The results of his study demonstrated that career policies, career development and career information do have a positive correlation with performance. It also provided evidence that career information has a stronger effect on performance, compared to the other two factors. 
With the concepts and needs in place, this study seeks to assess the influence of Career Management Implementation to Perceived Employee Performance among Baharanis in EKK. The results of the study will serve value in improving the existing career management program of the organization that would enable it to establish a career path framework for the talented employees and retain the key workers to achieve business advantage within Bahraini labor market competitors in accordance to the 2030 vision objectives.

\section{Theoretical Framework}

This research is anchored on three theories namely Two Dimensional Model of Career Management (Baruch \& Peiperl, 2000) which describe there are five dimensions under the career management: formal, basic, active management, active planning and multi directional however will explain the level of involvement and the level of sophistication. The second framework Heuristic Framework of Career Performance (Koopmans, 2017) explains the four dimensions: Task Performance, Adaptive Performance, Contextual Performance and Counterproductive work behavior and how its link to the work performance. Finally the third framework describes the relationship between the variables (Khulida Yahya, 2004).

Career management implementation significantly influence perceived level of performance for Bahrainis in Ebrahim Khalil Kanoo in Kingdom of Bahrain Researchers collect theoretical framework that include a philosophical and methodological model to help design their work. A formal theory provides context for the outcome of the events conducted in the research.

Baruch \& Peiperl (2000) built a framework of five practices dimensions on career management. "Basic" activities include job posting, formal education, preretirement programs, and lateral moves.

"Active Planning" activities were associated with dynamic, open, and proactive climates, include performance appraisal (by the direct supervisor and by the HR department) and succession planning. "Forman" activities include written personal career planning, supply dual career ladder, career books and/or pamphlets, and common career paths. "Multi-Directional" activities were correlated with open climates and include peer appraisal and upward appraisal. This model can provide an effective practice framework to managers to help employees' career development. "Active Management" cluster include assessment centers, formal mentoring relationships, and career workshops.

These activities all focus on knowing as much as possible about the individual and his/her prospects, as well as how the firm's career system works.

Research has shown the existence of a general factor, which accounts for substantial variation in job performance ratings.
At the second level, four dimensions of individual work performance are located. At the third level, the individual measures corresponding to each dimension are located. The importance of these dimensions, and the exact indicators associated with each dimension, may differ depending on the context involved. The first dimension, task performance, refers to the proficiency with which central job tasks are performed. The second dimension, contextual performance, refers to behaviors that support the organizational, social, and psychological environment in which the technical core must function. As a third dimension, adaptive performance is included in the heuristic framework.

Although proactive and creative performance can be a part of task performance in some jobs, we considered this part of contextual performance, as both contribute to a positive organizational, social, and psychological work environment. Each of the four dimensions is latent, meaning that they cannot be measured directly. Relations between dimensions not only are the separate dimensions related to the general factor of work performance, they are also related to each other.

Task performance is distinct, albeit strongly positively related, with contextual performance. Both types of behavior in- dependently contribute to overall performance, but through different means. Findings on the relation between task performance and counterproductive work behavior are inconclusive and have been found to be either moderately or strongly negative.

The inconclusive findings could be caused by differences in definition and measurement of task performance. When task performance is defined as what a person generally "will do," it is more strongly related to counterproductive work behavior than when task.

\section{METHODOLOGY}

The study utilized the descriptive design. An organizationally - based, descriptive portion of design was pursued through the use of relevant data via conducting adoptive questionnaire.

The respondents were selected from Ebrahim Khalil Kanoo Employees using quota sampling including those who are assigned in Tubli branch, Salmabad branch, Riffa branch, Arad branch and Manama branch. The total population is 450 bahrain employee and the researcher will take a sample of 162 respondents by using the published table used by Miller, Kunce (1973),Halinski and Feldt (1970) with margen error 0.05 .

The researcher used adopted questionnaire by (Baruch \& Peiperl, 2000) which has three parts: the first part will assess the status of career management implementation for Bahrainis in Ebrahim Khalil kanoo in 
the kingdom of Bahrain in term of: Multi Directional, Active Management, Active Planning, Formal and Basic.

The second part assessed the perceived on the level of performance for the respondents in the company in term of: Task Performance, Adaptive Performance, Contextual Performance and Counterproductive work behavior while the third part will be the open ended recommendation from the respondents.

The questionnaire was tested in terms of validity and reliability. In terms of validity, an assessment was done involving three experts in the field of career management. An assessment tool was used by the experts to evaluate the validity of the content. The results showed that the instrument was rated over all 4.2 weighted mean which are implemented career management and very good level of employee job performance. the three experts was from : Trust re reinsurance company which give the researcher 4.11 weighted mean overall , Ashraf Company in Bahrain 4.3 weighted mean and kumon company 4.32 weighted mean.

After validity was established, the reliability of the instrument was measured thru internal consistency. A pilot test was conducted involving 30 Bahraini employees who were not included in the final sample. A Chronbach alpha test yielded a value of 0.82 indicating the internal consistency of the instrument.

The data gathering was organized, analyzed and interpreted using the following statistical tools: mean, standard deviation, multiple linear and regression analysis.

\section{PRESENTATION, ANALYSIS AND INTERPRETATION OF DATA}

\section{A. Career Management Implementation}

Table 3.1

Status of Career Management Implementation in Terms of Basic Activities

\begin{tabular}{lrrl}
\hline \multicolumn{1}{c}{ Indicators } & $S D$ & $X$ & Interpretation \\
\hline $\begin{array}{l}\text { The organization } \\
\text { appropriately utilizes job } \\
\text { postings. }\end{array}$ & 1.00 & 4.18 & Implemented \\
$\begin{array}{l}\text { The organization } \\
\text { employs mechanisms for } \\
\text { employees to be part of } \\
\text { formal trainings outside } \\
\text { the organization. }\end{array}$ & 1.09 & 3.96 & Implemented \\
$\begin{array}{l}\text { EKK implements } \\
\text { programs to help } \\
\text { employees prepare for } \\
\text { retirement. }\end{array}$ & 1.23 & 3.78 & Implemented \\
$\begin{array}{l}\text { EKK employs } \\
\text { appropriate lateral } \\
\text { transfer of employees }\end{array}$ & 1.11 & 3.90 & Implemented \\
\hline
\end{tabular}

\begin{tabular}{llll}
\hline Over-all & 1.12 & 3.95 & Implemented \\
\hline
\end{tabular}

Table 3.1 shows the status of career management in term of basic activities. As what can be gleaned from the table, the over-all the status of career management in Ebrahim Khalil Kanoo in term of basic activities is good career management implementation $(x=3.95, S D=1.12)$. This would suggest that the organization implements career management procedures and activities that convey clear messages to employees that focus their efforts and attention for future career development.

Conlon (2017) noted that the organization should train its employee quarterly by sending them to professional training workshops locally and externally to improve their ability and skills to enable them to develop and maintain their career.

Table 3.2

Status of Career Management Implementation in Terms of Formal Activities

\begin{tabular}{|c|c|c|c|}
\hline Indicators & $S D$ & $X$ & Qualitative \\
\hline $\begin{array}{l}\text { EKK keeps records of } \\
\text { employees' personal } \\
\text { career plan. }\end{array}$ & 1.26 & 3.80 & Implemented \\
\hline $\begin{array}{l}\text { The organization } \\
\text { employs a } \\
\text { development plan that } \\
\text { allows upward } \\
\text { mobility for employees } \\
\text { without requiring them } \\
\text { to be placed into } \\
\text { supervisory or } \\
\text { managerial positions. }\end{array}$ & 1.17 & 3.77 & Implemented \\
\hline $\begin{array}{l}\text { EKK circulates career } \\
\text { books and pamphlets }\end{array}$ & 1.27 & 3.85 & Implemented \\
\hline $\begin{array}{l}\text { In EKK, employee } \\
\text { moves on one by one } \\
\text { as he grows in an } \\
\text { organization }\end{array}$ & 1.18 & 4.02 & Implemented \\
\hline Over-all & 1.22 & 3.86 & Implemented \\
\hline
\end{tabular}

Table 3.2 shows the status of career management in term of formal activities. The weighted mean of 3.86 $(S D=1.22)$ indicates good career management implementation. The respondents' opinion in this matter seems to be varied as evidenced by the high value of standard deviation. This would mean that the organization adopts an inclusive and welcoming approach that meets the needs of all employees.

Super (2014) suggested that each employee in any organization should have a career plan and career pathway to transfer from their current grade to upper grade to improve their career plan. 
Table 3.3

Status of Career Management Implementation in Terms of Directional Activities

\begin{tabular}{lrrl}
\hline Indicators & $S D$ & $X$ & Interpretation \\
\hline $\begin{array}{l}\text { In my organization, } \\
\text { employees can freely } \\
\text { evaluate each other }\end{array}$ & 1.13 & 3.93 & Implemented \\
$\begin{array}{l}\text { Superiors are } \\
\text { appropriately evaluated } \\
\text { by the subordinates. }\end{array}$ & 1.18 & 3.81 & Implemented \\
\hline Over-all & $\mathbf{1 . 1 6}$ & $\mathbf{3 . 8 7}$ & Implemented \\
\hline
\end{tabular}

Table 3.3 shows the status of career management in term of multi directional. As what can be gleaned from the table, the over-all mean indicates that the organization has in place a good level of implementation $(x=3.87$, $S D=1.16$ ). However, the respondents' opinion in this matter seems to be varied as evidenced by the high value of standard deviation.

Table 3.4

Status of Career Management in Terms of Active Management

\begin{tabular}{lrrl}
\hline Indicators & $S D$ & $X$ & Interpretation \\
\hline $\begin{array}{l}\text { Assessment canters are } \\
\text { established in EKK for } \\
\text { objective evaluations }\end{array}$ & 1.12 & 3.98 & Implemented \\
$\begin{array}{l}\text { EKK have seniors } \\
\text { mentor juniors and new }\end{array}$ & 1.10 & 4.12 & Implemented \\
$\begin{array}{l}\text { hires } \\
\begin{array}{l}\text { Career workshops are } \\
\text { organized by the } \\
\text { organization }\end{array}\end{array}$ & 1.11 & 3.94 & Implemented \\
\hline Over-all & $\mathbf{1 . 1 1}$ & $\mathbf{4 . 0 1}$ & Implemented \\
\hline
\end{tabular}

The status of career management in term of active management shown in Table 4.4. As what can be gleaned from the table, the overall mean of this dimension is rated at $4.01(S D=1.11)$ suggesting a good level of implementation.

The organization demonstrates good practices having seniors mentor juniors and new hires, organizing career workshops by the organization, assessment canters are established in EKK for objective evaluations. This is a good sign for Ebrahim Khalil Kanoo as Organizational policies and practices that relate to the availability of resources and support to improve the career management within the company

Table 3.5

Status of Career Management in Terms of Active planning

\begin{tabular}{llll}
\hline Indicators & $S D$ & $X$ & Interpretation \\
\hline $\begin{array}{l}\text { In EKK, Performance } \\
\text { appraisal as a basis for }\end{array}$ & 1.22 & 3.91 & Implemented
\end{tabular}

career planning

Direct supervisors

objectively evaluates

subordinates

HR Department appropriately plans the career moves of the employees

Succession planning is effectively implemented in EKK

\begin{tabular}{llll}
\hline Over-all & 1.22 & 3.85 & Implemented
\end{tabular}

Finally, table 3.5 shows the status of career management in term of active planning. As what is presented in the table, the over-all weighted mean suggests $(\mathrm{x}=3.85, \mathrm{SD}=1.22)$. This would mean that, in general, the organization is implementing the career management internally with the employees in a good level. In fact, employees say they Performance appraisal as a basis for career planning. In addition, direct supervisors objectively evaluate subordinates. In addition, Succession planning is effectively implemented in EKK. While the HR Department appropriately plans the career moves of the employees.

\section{B. Perceived Job Performance}

Table 3.6

Perceived Level of Performance

\begin{tabular}{|c|c|c|c|}
\hline $\begin{array}{l}\text { Indicators } \\
\text { TASK PERFORMANCE }\end{array}$ & $S D$ & $X$ & Interpretation \\
\hline $\begin{array}{l}\text { I complete the given tasks } \\
\text { on time. }\end{array}$ & 1.02 & 4.16 & Very good \\
\hline $\begin{array}{l}\text { My output is considered by } \\
\text { my superior neat and } \\
\text { accurate. }\end{array}$ & 0.95 & 4.09 & Very good \\
\hline $\begin{array}{l}\text { If given a chance, I solve } \\
\text { work problems effectively }\end{array}$ & 0.99 & 4.27 & Excellent \\
\hline $\begin{array}{l}\text { I am capable of making } \\
\text { sure that in my work, } \\
\text { resources are properly } \\
\text { utilized. }\end{array}$ & 0.95 & 4.10 & Very good \\
\hline $\begin{array}{l}\text { I am organized in } \\
\text { dispensing my tasks in } \\
\text { work. }\end{array}$ & 1.06 & 4.10 & Very good \\
\hline \multicolumn{4}{|c|}{ CONTEXTUAL PERFORMANCE } \\
\hline $\begin{array}{l}\text { I perform my job with } \\
\text { enthusiasm }\end{array}$ & 1.04 & 4.17 & Very good \\
\hline $\begin{array}{l}\text { I take initiative when I see } \\
\text { it necessary }\end{array}$ & 0.99 & 4.23 & Excellent \\
\hline I am creative in my work & 1.04 & 4.19 & Very good \\
\hline $\begin{array}{l}\text { I help my co-workers in } \\
\text { times when they are in need }\end{array}$ & 1.01 & 4.28 & Excellent \\
\hline $\begin{array}{l}\text { I am persistent in doing the } \\
\text { things I do in work. }\end{array}$ & 1.01 & 4.20 & Very good \\
\hline \multicolumn{4}{|l|}{ ADAPTIVE PERFORMANCE } \\
\hline
\end{tabular}




\begin{tabular}{|c|c|c|c|}
\hline \multicolumn{4}{|l|}{ work. } \\
\hline $\begin{array}{l}\text { I easily adjust to changes in } \\
\text { work policies }\end{array}$ & 1.00 & 4.06 & Very good \\
\hline $\begin{array}{l}\text { I embrace cultural diversity } \\
\text { in the workplace }\end{array}$ & 0.97 & 4.19 & Very good \\
\hline $\begin{array}{l}\text { I easily learn the new tasks } \\
\text { given to me }\end{array}$ & 0.97 & 4.28 & Excellent \\
\hline $\begin{array}{l}\text { In work, I stay calm under } \\
\text { pressure. }\end{array}$ & 1.06 & 4.06 & Very good \\
\hline \multicolumn{4}{|c|}{ COUNTER PRODUCTIVE BEHAVIOURS } \\
\hline $\begin{array}{l}\text { If given an opportunity, I will } \\
\text { not take longer breaks than } \\
\text { allowed }\end{array}$ & 1.26 & 4.77 & Very good \\
\hline $\begin{array}{l}\text { I will not participate in office } \\
\text { gossip about our superiors } \\
\text { and co-workers. }\end{array}$ & 1.22 & 4.83 & Very good \\
\hline $\begin{array}{l}\text { I regard safety in performing } \\
\text { my job. }\end{array}$ & 1.27 & 4.73 & Very good \\
\hline $\begin{array}{l}\text { I don't take absences even } \\
\text { without a valid reason. }\end{array}$ & 1.34 & 4.67 & Very good \\
\hline I never been late in work. & 1.26 & 4.64 & Very good \\
\hline $\begin{array}{l}\text { Over-all Employee } \\
\text { Performance }\end{array}$ & 0.13 & 3.55 & Very good \\
\hline
\end{tabular}

Table 3.6 shows the perceived employee performance in Ebrahim Khalil Kanoo. As the over-all results show, as perceived by the respondents, the organization is performing at a very good level $(x=3.55$, $S D=0.13$ ) in terms of task performance, contextual performance, adoptive performance and counterproductive behaviors.

Looking at the individual dimensions, contextual performance tends to be the highest contributor of the company overall performance. It is an evidence that the employees are highly engaged in their work by doing their job and extra work, being innovative bringing new idea to be implemented, have the inspiration and the motivation to do the job effectively and efficiency .Besides it means that the company cares about the employee and it makes effort to satisfy the employee. As well as the Counter Productive Behaviors which is excellent as the employee love their jobs and happy to be part of the organization and well engaged.

\section{Career Management Implementation and its Influence Perceived Level of Performance}

Table 3.7

Regression Statistics for the Influence of Career Management Implementation on Perceived level of performance

\begin{tabular}{lr}
\hline Multiple R & 0.60287 \\
R Square & 0.36345 \\
Adjusted R Square & 0.34305 \\
Standard Error & 0.44580 \\
Observations & 162 \\
\hline
\end{tabular}

Table 3.7 presents the Regression Analysis to test the influence of career management implementation on respondents' perceived level of performance. As the table shows, table 4.8 present the computed $F$ value is 17.8145 which is significant at $0.01(p<0.01)$. This means that overall implementation of Career Management significantly influences the employee's perceived level of performance. In fact, the computed adjusted $R$ square suggests that around $34 \%$ of the variations in performance are influenced by Career Management Implementation.

Table 3.8

Analysis of Variance

\begin{tabular}{lrrrrr}
\hline & df & SS & MS & F & Significance \\
\hline Regression & 5 & 17.70 & 3.54 & 17.8 & $6.01^{\mathrm{E}-14}$ \\
Residual & 156 & 31.00 & 0.19 & & \\
Total & 161 & 48.70 & & & \\
\hline
\end{tabular}

Table 3.9

Regression Coefficients

\begin{tabular}{|c|c|c|c|c|}
\hline & Coefficients & SE & $\mathrm{t}$ & $P$ \\
\hline Intercept & 2.176 & 0.162 & 13.424 & $8.407^{\mathrm{E}-28 * *}$ \\
\hline Bas-Act & 0.188 & 0.073 & 2.556 & $0.011^{*}$ \\
\hline Form & -0.167 & 0.076 & -2.205 & $0.028^{*}$ \\
\hline Mult-Direc & -0.07 & 0.049 & -1.416 & 0.158 \\
\hline Act-Mgt & 0.206 & 0.067 & 3.083 & $0.002 * *$ \\
\hline Act-Plan & 0.187 & 0.066 & 2.841 & $0.005^{* *}$ \\
\hline${ }^{* *}$ significant at 0.01 & \multicolumn{4}{|l|}{ Legend: } \\
\hline${ }^{* *}$ significant at 0.05 & \multicolumn{4}{|c|}{$\begin{array}{l}\text { Form }=\text { formal activities } \\
\text { Mult-Direc }=\text { Multi-directional }\end{array}$} \\
\hline
\end{tabular}

Looking at Table 4.9 the individual dimensions of Career Management Implementation, however, only MultiDirectional Activity does not significantly influence Perceived Employee Performance $(p=0.158)$. Both Basic and Formal Activities are significant at 0.05 in influencing Perceived Performance with $\mathrm{p}$ values of 0.011 and 0.028 respectively. Finally, Active Planning and Active Management Activities are significant at 0.01 with $\mathrm{p}$ values of 0.005 and 0.002 , respectively.

\section{CONCLUSION}

After careful analysis of the findings of the study, the researcher derived several conclusions. Firstly, the study concludes that over-all implementation of Career Management influences perceived employee performance. Second, the study also found that among all dimensions of Career Management assessed in the study, Basic, Formal, Active Planning and Active Management Activities significantly influence Perceived Employee Performance. Finally, Multi-Directional Activity does not significantly influence perceived employee performance. 


\section{RECOMMENDATION}

Based on the findings of the study, the following recommendations are set forth;

1. EKK should improve more in implementing programs to help employees to be prepared for retirement. The researcher suggests to put the retirement details in first contract by the recruitment department to let the employee plan well from inception for his retirement.

2. Organizations need to design programs and initiatives for career management in such a way that they can be seamlessly integrated into the organization and that workers see them as a chance to increase their productivity and their learning.

3. EKK needs to design programs and initiatives for career management in such a way that they can be seamlessly integrated into the organization and that workers see them as a chance to increase their productivity and their learning. To ensure longterm growth through the career pathway, organizations need to emphasize the integration and learning perspective as a motivation for both administrators and its workforce.

4. Finally, future research should be conducted about career management with special attention on the varying effects of the dimensions. More respondents may be included to have more conclusive findings. Also the heuristic framework of individual work performance that is presented in the current review can serve as a guide for future research and practice.

\section{REFERENCES}

[1] Adamson. (2015). A study about the importance of career management. International Journal of Career Management in UK, 444-555.

[2] Orpen. (2014). The effects of organizational and individual career management on career success. International Journal of Manpower, 15(1), 27-37.

[3] Kulida Yahya. (2004). The relationship between organization career management and individual's performance. Available at:

http://citeseerx.ist.psu.edu/viewdoc/download?doi=10.1.1.4 $70.7415 \&$ rep $=$ rep $1 \&$ type $=$ pdf.

[4] Conlon. (2004). Employee training and workshop internally and externally Career. UK Journal, 34, 84-85.

[5] Super, Donald E. (2014). Career plan approach to career management. Journal of Vocational Behavior, 16, 282298.

[6] Koopman. (2017). Four dimension of career performance. The International Journal of Public Sector Management, 13(5), 417-446.

[7] Baruch, Y. \& Peiperl. M. (2000). Career management practices: An empirical survey and implications. Human Resource Management Book, Wiley Online Library, 347366.

[8] Miller, D. E. \& Kunce, J. T. (1973). Prediction and statistical overkill revisited. Measurement and Evaluation in Guidance, 6(3), 157-163.

[9] Halinski \& Feldt. (1970). Prediction and statistical overkill revisited. Measurement and Evaluation in Guidance, 6(3), 164-167. 